\title{
Genotoxic Effect of Lead and Cadmium on Workers at Wastewater Plant in Iraq
}

\author{
Salih Ibrahem $\mathbb{D}^{1}{ }^{1}$ Muna Hassan, ${ }^{2}$ Qais Ibraheem, ${ }^{3}$ and Khalid Arif ${ }^{4}$ \\ ${ }^{1}$ Department of Biochemistry, College of Medicine, Kirkuk University, Kirkuk, Iraq \\ ${ }^{2}$ Department of Biochemistry, College of Medicine, Al-Nahrain University, Baghdad, Iraq \\ ${ }^{3}$ Department of Biochemistry, Faculty of Agricultural Engineering Sciences, Baghdad University, Baghdad, Iraq \\ ${ }^{4}$ Department of Physiology, College of Medicine, Kirkuk University, Kirkuk, Iraq \\ Correspondence should be addressed to Salih Ibrahem; salih.ibrahem@uokirkuk.edu.iq
}

Received 4 December 2019; Revised 13 June 2020; Accepted 4 July 2020; Published 25 July 2020

Academic Editor: Ike S. Okosun

Copyright (c) 2020 Salih Ibrahem et al. This is an open access article distributed under the Creative Commons Attribution License, which permits unrestricted use, distribution, and reproduction in any medium, provided the original work is properly cited.

\begin{abstract}
Heavy metal poisoning is a worldwide problem that is caused by different human industrial activities such as battery and painting manufacturing and occupational exposure of those working at petrol stations. Wastewater is known to contain higher amounts of heavy metals such as lead (Pd) and cadmium (Cd) and might be sources of exposure for workers at the wastewater treatment plant. However, to our best knowledge, no studies were done to evaluate the level of cadmium and lead in blood of workers at wastewater treatment plants and evaluate the subsequent effect of lead and cadmium on delta-aminolevulinic acid dehydratase $(\delta$-ALAD), urinary delta-aminolevulinic acid (U $\delta$-ALA), and 8-hydroxy-2'-deoxyguanosine (8-OHdG) as markers of lead and cadmium toxicity. In this case-control study, 79 workers at the Al-Rustumiya wastewater plant in Baghdad, Iraq, and 40 control subjects were included. The levels of lead and cadmium were measured in blood of the study subjects using the atomic absorption spectroscopy (AAS) method. 8-OHdG was analysed using enzyme-linked immunosorbent assay (ELISA) technique. $\delta$-ALAD and U $\delta$-ALA were estimated using spectrophotometry-based methods. Our work showed that workers had a significantly higher level of lead and cadmium when compared with the control group $(P<0.05)$, yet, still within the World Health Organization permissible limit. The level of both metals was positively associated with duration of work at the plant $(P<0.01)$. The activity of $\delta$-ALAD was inversely associated with the lead level, while both U $\delta$-ALA and 8-OHdG were positively correlated with the lead level $(P<0.05)$. These three markers lacked any statistically significant association with the cadmium level $(P>0.05)$. To sum up, working at the wastewater treatment plant was associated with a higher blood level of lead and cadmium and their possible health hazard. Health and occupational safety authorities are required to set up tighter regulations and protocols to minimize these hazards and ensure a safe working environment.
\end{abstract}

\section{Introduction}

Wastewater is a complex mixture of water carrying waste that is drained from residential, commercial, and industrial establishments [1]. Because sources of waste are different, wastewater contains biological hazard materials, relatively large amounts of possible carcinogens and heavy metals [2-4]. Fruits and vegetables irrigated with wastewater or treated with its sludge as a fertilizer include levels of heavy metals such as lead and cadmium that exceeded the permissible limits established by the World Health Organization (WHO) and the Chinese State Environmental Protection Administration (SEPA) $[5,6]$.
Heavy metals can be defined as any metallic elements with relatively high density when compared to water; these metals are toxic or poisonous even at minute concentrations [7]. Toxic inorganic heavy metals such as lead (Pb) and cadmium $(\mathrm{Cd})$ are found in the Earth's crust and released to the environment due to human industrial activities such as metal plating, mining, battery production, smelting operations, and paint production [8].

Lead and cadmium are pollutants and are not, normally, present in the human body and have no reported beneficial biochemical activity [9]. Heavy metals are characterised by high solubility in the aqueous solutions and quick 
absorption by all living organisms [10]. These two features allow these metals to be present in almost all tissues and organs [10]. The concentration of these metals in the human body (bioavailability) is a function of physical (temperature, adsorption, and sequestration) and biochemical factors, which play a role in complexation kinetics, speciation, and lipid solubility [8].

Lead compounds were classified by the International Agency for Research on Cancer (IARC) as Group 2A carcinogens (likely to cause human cancer) and as probable human carcinogens by the US Environmental Protection Agency (EPA) [11, 12]. Lead gets access to the body through either ingestion, inhalation of arousal, or contact with skin of lead-containg materials [13]. Exposure to lead causes genotoxic effects such as chromosome aberration, mutation, DNA breakage, and DNA synthesis inhibition [14]. Markers of nuclear and mitochondrial DNA damage due to lead and cadmium toxicity include 8-hydroxyguanine (8-oxo-7,8dihydroguanine), 8-hydroxy-2' -deoxyguanosine (8-OHdG), or 8-oxo-7,8-dihydro-2'-deoxyguanosine (8-oxodG) [15]. 8$\mathrm{OHdG}$ is the main form of DNA damage induced by free radicals, which is used as a measurable biomarker for DNA oxidative stress and carcinogenesis [15].

The deleterious effect of lead extends to some enzymes such as delta-aminolevulinic dehydratase ( $\delta$-ALAD), and this enzyme activity inhibition is a sensitive marker of lead toxicity $[12,16]$. Inhibition of $\delta$-ALAD impairs the condensation of two molecules of delta-aminolevulinic acid to form porphobilinogen (PBG) in the pathway for haemoglobin biosysnthesis, which leads to the accumulation of ALA in blood with subsequent overflow excretion in urine $[13,17]$. $\delta$-ALA accumulation stimulates the production of reactive oxygen species (ROS) that culminate in oxidative stress, with generation of 4,5-dioxovaleric acid as the ALA final oxidation product $[9,18]$. 4,5-Dioxovaleric acid is an effective alkylating agent of the quinine moieties within both nucleoside and isolated DNA [18]. Alkylation increases the level of 8-oxo-7,8-dihydro-2-deoxyguanosine and 5-hydroxyl-2-deoxycytidine [18].

Cadmium poisoning is a worldwide health concern, which was reported by different countries, and its carcinogenic effects are well recognised [19]. Similar to lead, cadmium (Cd) was classified by the IARC as Group 1 human carcinogen and was considered Group 2a human carcinogen by the EPA [16]. Cadmium enters the human body through different contaminated elements such as air, water, soil, and food [20]. The spectrum of cadmium toxicity consequences ranges from cancer to toxicity of skeletal, urinary, reproductive, cardiovascular, nervous, and respiratory systems [20]. Cadmium delivers its toxic and carcinogenic effects by competitive binding to areas in enzymes, proteins, and DNA (specifically with a zinc finger motif), which are vital for gene regulation, enzyme activity, or maintenance of genomic stability [21]. It also impairs mitochondrial electron transport and stimulates cellular reactive oxygen species generation [22].

The serious and wide-spread toxic effects of lead and cadmium have been a hotspot for research studies in different disease settings and countries, and many meta-analyses were published about the studies in this field [23-27].
Wastewater, as explained earlier, includes high concentration of heavy metals, namely, lead and cadmium, and thus, workers at wastewater might be at a greater risk of the exposure to these metals. However, no study was done, at least in Iraq, to analyse the level of lead and cadmium in blood and their genotoxic effects of the workers at wastewater treatment plants. In this work, we will examine the occupational effect on the level of lead and cadmium and their possible effect on the DNA by measurement of 8 OHdG. We also tried to identify the mechanism by which these metals exert their genotoxic effect by estimation of $\delta$-ALAD and U $\delta$-ALA.

\section{Subjects, Materials, and Methods}

2.1. Al-Rustumiya Wastewater Treatment Plant: An Overview. The plant was built in 1963 and is located on the south-east side of Baghdad, the capital of Iraq, and treats wastewater that is drained from different parts of the capital. The drained area has a population of nearly 3 million and occupied by residential areas, industrial states, and 28 hospitals [28]. Treated water then re-enters the river of Diyala [28]. The plant has seen many expansions to cope with the increase in the population and industrial activities [28].

2.2. Study Subjects. This case-control study contained two groups. The first consisted of 79 workers at the Al-Rustumiya wastewater treatment plant, sixty males and 19 females, with age range of 18-65 years (mean and SD 37.06 \pm 12.18 ). The second is the control group of 40 healthy volunteers, who are not working at similar occupations, with matching sex, age, and body mass index (BMI); both groups were from Baghdad. The study was done over a 6-month period from the $1^{\text {st }}$ of October 2016 till the $31^{\text {st }}$ of March 2017.

All subjects were informed about the purposes, benefits, and risks of the study, as well as their right to withdraw at any time in accordance with the Declaration of Helsinki (1964). The study was approved by Al-Nahrain University, Medical College Ethics Committee.

Medical, surgical, and drug intake and occupational history were taken. We excluded those who work at leadand cadmium-related fields such as petrol stations, battery industry, lead-based painting, pottery, plating, soldering, welding, and printing of books. Cigarette smoking is marked by the increase of blood cadmium; thus, smokers were also exempted from our study [21].

2.3. Materials. The laboratory investigations were performed at the Department of Chemistry and Biochemistry at the College of Medicine, Al-Nahrain University, Baghdad, Iraq. They included measurement of blood lead $(\mathrm{Pb})$, cadmium $(\mathrm{Cd}), 8-\mathrm{OHdG}$ and $\delta$-ALAD levels, and estimation of urine concentration of $\delta$-ALA.

Morning peripheral venous blood samples were collected between 9:00 AM and 11:00 AM. Serum was obtained from five millilitres $(\mathrm{ml})$ of peripheral venous blood that was collected in a plain tube and centrifuged using the 
Medifuge $^{\mathrm{TM}}$ machine (Thermo Fisher Scientific ${ }^{\mathrm{TM}}$, USA) for 15 minutes $(\mathrm{min})$ at $3000 \mathrm{rpm}(755 \times \mathrm{g})$ following clotting. Serum samples were then frozen at $-20^{\circ} \mathrm{C}$ in small aliquots until further analysis within 6-month period for 8-DHoG, while heparinised whole blood was used to measure the concentration of $\mathrm{Pb}, \mathrm{Cd}$, and erythrocyte $\delta$-ALAD enzyme activity.

Random urine samples were used to measure $\delta$-ALA (UALA) instead of 24-hour urine sample collection to avoid possible errors from the inadequate and improper collection.

Throughout the study, strict precautions were exercised to prevent contamination of the samples, test reagents, and equipment with lead and cadmium according to the Clinical and Laboratory Standards Institute criteria [29].

\subsection{Methods}

2.4.1. Determination of Lead and Cadmium Concentration in Whole Blood. Shimadzu model AA-6300G ${ }^{\circledR}$ atomic absorption spectrometer (Kyoto, Japan) with the GFA-EX7i graphite furnace atomizer (to vaporize the sample) was used to measure lead and cadmium as described by Subramanian and Meranger [30]. In brief, heparinised whole blood samples and standards were diluted at a ratio of $1: 10$ with distilled water, and whole blood was then homogenised with $25 \mathrm{ml}$ of $10 \%$ triton $\mathrm{X}-100$ (Sigma-Aldrich ${ }^{\circledR}$ Company, Germany). $5 \mathrm{ml}$ of $20 \%$ ammonium dihydrogen phosphate (Merck-Darmstadt ${ }^{\circledR}$, Germany), with $1 \mathrm{ml}$ of concentrated nitric acid (BDH Chemicals $\left.{ }^{\circledR}, \mathrm{UK}\right)$ was then added to the sample, and the volume was titrated to $500 \mathrm{ml}$ with distilled water. The measurement was done at $283 \mathrm{~nm}$ and $228 \mathrm{~nm}$ for lead and cadmium, respectively. The results were presented as $\mu \mathrm{g} / \mathrm{dl}$.

\subsubsection{Estimation of the Activity of Delta-Aminolevulinic Acid} Dehydratase $(\delta-A L A D)$ in Erythrocytes. The concentration of $\delta$-ALAD in whole blood was measured using Burch and Siegel method as previously described [31]. Shortly, $0.2 \mathrm{ml}$ of heparinised whole blood was homogenised with $1.3 \mathrm{ml}$ of Triton X-100 (Sigma-Aldrich ${ }^{\circledR}$ Company, Germany) and then $1 \mathrm{ml}$ of buffered ALA substrate was added and mixed well. $1 \mathrm{ml}$ of the resultant mixture was utilised as blank. The remaining amount was then incubated at stable $\mathrm{pH}(7.0)$ for one hour at $38^{\circ} \mathrm{C}$ followed by the addition of $1 \mathrm{ml}$ of the TCA reagent and then mixed well and centrifuged. $1 \mathrm{ml}$ of the supernatant was used as the sample. $1 \mathrm{ml}$ of modified Ehrlich's reagent (Sigma-Aldrich ${ }^{\circledR}$ Company, Germany) was added to the already prepared $1 \mathrm{ml}$ of blank and sample tubes and allowed to react. The tubes were allowed to develop colour for 13 minutes before measuring absorbance at $555 \mathrm{~nm}$ using a spectrophotometer (Biotech-UV2601 ${ }^{\circledR}$-UK). The results are expressed as $\mathrm{mmol} / \mathrm{ml}$ of erythrocyte/hr.

\subsubsection{Determination of Urinary $\delta$-ALA Concentration.} The measurement of $\mathrm{U} \delta$-ALA was performed according to the method described by Wada et al. [32]. This method depends on the development of reddish colour when chloroform is added to urine containing high amount of $\delta$-ALA, while faint yellow or faint red colour represents normal amounts of $\delta$-ALA in urine. In brief, we added $2 \mathrm{ml}$ of $20 \%$ acetic acid solution to a tube containing $2 \mathrm{ml}$ of urine followed by loading $8 \mathrm{ml}$ of $n$-butanol to the mixture and homogenised it well using the vortex shaker (Vortex-Genie ${ }^{\circledR}$, Scientific Industries, USA). Two test tubes were then used; each tube contained $0.5 \mathrm{ml}$ of the mixture aqueous part, one was used as a blank after adding $1.5 \mathrm{ml}$ of sodium phosphate buffer only, while the other (sample tube) was loaded with $1.5 \mathrm{ml}$ of sodium phosphate buffer containing ethyl acetoacetate. Following ten minutes of incubation of both tubes in boiling water, they were allowed to cool down. Then, $2 \mathrm{ml}$ of Ehrlich's reagent (Sigma-Aldrich ${ }^{\circledR}$ Company, Germany) was mixed. The samples were allowed to settle down for another ten minutes; after that, $4 \mathrm{ml}$ of chloroform was added and mixed well with the vortex shaker. After 5 to $30 \mathrm{~min}$, the absorbance of the chloroform phase was read at $556 \mathrm{~nm}$ by the spectrophotometer (Biotech-UV2601 ${ }^{\circledR}-\mathrm{UK}$ ) against the blank. The concentration in urine was shown as $\mu \mathrm{mol} / \mathrm{l}$.

2.4.4. Measurement of 8-Hydroxyl-2-deoxyguanosine (8-OHdG) Concentration. The level of $8-\mathrm{OHdG}$ was measured depending on enzyme-linked immunosorbent assay (ELISA) technology. The measurement kit was supplied by Cayman Chemical ${ }^{\circledR}$ (USA, Michigan 48108, Kit no. 89320) and used according to the manufacturer's instructions. Biotek ELx800 ${ }^{\circledR}$ ELISA system (BioTek Instruments, Inc., USA) was used for reading absorbance at $450 \mathrm{~nm}$, and the result was expressed as $\mathrm{ng} / \mathrm{ml}$.

2.5. Statistical Analysis. GraphPad Prism $8^{\circledR}$ software (San Diego, CA, USA) was utilised to generate figures and perform statistical analysis. Unpaired Student's $t$-test was used to compare the variables of the two groups. Pearson correlation was applied to study the correlations between various variables depending on the correlation coefficient and $P$ value. $P$ values $<0.05$ were considered statistically significant. Test for normality was done using the Kolmogorov-Smirnov test of normality.

\section{Results}

3.1. Study Population. There were no statistically significant differences between the worker and control groups with regard to age, sex, body mass index, and haemoglobin $(P>0.05$, Table 1$)$. The clinicodemographic characteristics of our worker group showed that the age range was 18-65 years with male dominance (80\%). Numerical details are shown in Table 1.

3.2. Level of Lead and Other Variables and Their Association. The mean blood level of lead $(\mathrm{Pb})$ of the worker group $(5.2 \mu \mathrm{g} / \mathrm{dl})$ was significantly higher $(P<0.0001)$ when compared with the mean level of the control one $(1.03 \mu \mathrm{g} / \mathrm{dl})$, 
TABLE 1: Clinicodemographic characteristics of the study population, both the worker group and the control one. Both groups have no differences of statistical significance with regard to the parameters; SD is standard deviation.

\begin{tabular}{|c|c|c|c|}
\hline Parameter & Control group & Worker group & $P$ value \\
\hline Age $($ mean \pm SD) (years) & $\begin{array}{c}36.87 \pm 11.7 \\
(24-60 \text { years })\end{array}$ & $\begin{array}{l}37.06 \pm 14.18 \\
(18-65 \text { years })\end{array}$ & $>0.05$ \\
\hline \multicolumn{4}{|l|}{ Sex } \\
\hline $\begin{array}{l}\text { Male } \\
\text { Female }\end{array}$ & $\begin{array}{l}80 \% \\
20 \%\end{array}$ & $\begin{array}{l}75 \% \\
25 \%\end{array}$ & $>0.05$ \\
\hline BMI $($ mean \pm SD) $(\mathrm{kg} / \mathrm{m})$ & $25.73 \pm 2.2$ & $27.09 \pm 4.96$ & $>0.05$ \\
\hline $\begin{array}{l}\text { Duration in work/years } \\
0-10 \text { years } \\
11-20 \text { years } \\
21-30 \text { years } \\
31-40 \text { years }\end{array}$ & & $\begin{array}{c}57(72.2 \%) \\
17(21.5 \%) \\
2(2.5 \%) \\
3(3.8 \%) \\
\end{array}$ & \\
\hline $\begin{array}{l}\text { Haemoglobin, Hb (g/dl) } \\
\text { Mean } \pm \text { SD }\end{array}$ & $13.5 \pm 1.0$ & $13.9 \pm 1.2$ & $>0.05$ \\
\hline
\end{tabular}

as can be seen in Figure 1. Gender has no influence on the level of lead within the same group $(P>0.05)$.

The level of lead was positively associated with duration of working (correlation coefficient, $r$ : $0.86,95 \%$ confidence interval, CI: 0.79 to $0.91, P<0.0001)$, as clarified in Figure 2(a). As shown in Figure 2(b), it was interesting to find that the ALAD level showed inverse correlation with the lead level ( $r$ : $-0.99,95 \% \mathrm{CI}:-0.99$ to $-0.97, P<0.0001)$. There was a significant positive correlation between the level of urinary ALA and lead ( $r$ : $0.88,95 \%$ CI: 0.82 to 0.92 , $P<0.0001)$, as depicted in Figure 2(c). Figure 2(d) shows that there is a positive significant correlation between 8 DHoG level and lead concentration ( $r: 0.88,95 \%$ CI: 0.82 to 0.92, $P<0.0001)$.

3.3. Level of Cadmium and Other Variables and Their Association. There was significantly higher concentration $(P<0.0001)$ of cadmium in blood of the worker group (mean, $0.34 \mu \mathrm{g} / \mathrm{dl}$ ) in comparison with the control group (mean, $0.16 \mu \mathrm{g} / \mathrm{dl}$ ), as shown in Figure 3.

We found that the level of cadmium in blood is positively associated with the length of working at the plant (Figure $4(\mathrm{a}))(r: 0.81,95 \% \mathrm{CI}: 0.73$ to $0.92, P<0.0001)$.

The level of $\delta$-ALAD is not associated with cadmium concentration ( $r$ : $0.13,95 \% \mathrm{CI}:-0.09$ to $0.34, P=0.242)$, as visually depicted in Figure 4(b). Another variable we measured was urinary $\delta$-aminolevulinic acid (U $\delta$-ALA), which showed no correlation with cadmium concentration, as shown in Figure 4(c) and confirmed statistically ( $r: 0.14$, 95\% CI: -0.087 to $0.35, P=0.23$ ). The last variable we assessed was DNA damage marker $8-\mathrm{OHdG}$ which showed no association with the cadmium level ( $r$ : 0.14, 95\% CI: -0.05 to $0.35, P=0.23$ ) (Figure $4(\mathrm{~d})$ ).

\section{Discussion}

It is generally accepted that lead and cadmium are present in high concentration in wastewater, and these metals have high rate of absorption and long half-life once they get access

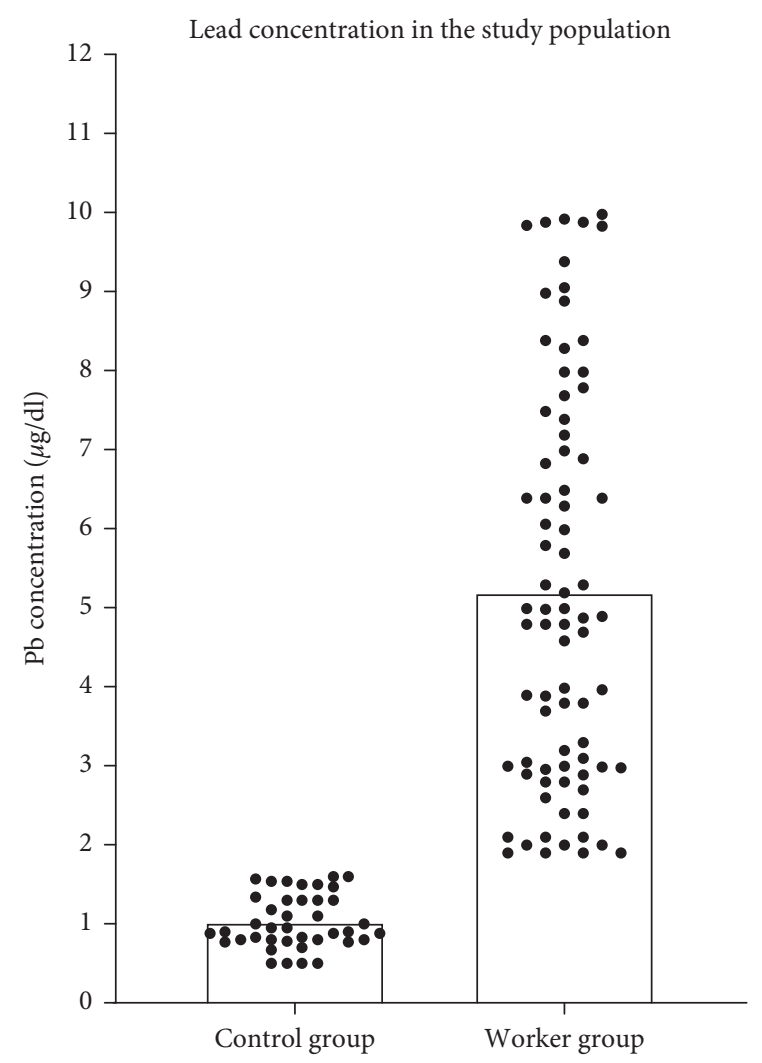

FIgURE 1: The concentration of lead in the wastewater treatment plant workers is almost five times higher than the amount found in the control group $(P<0.0001)$.

to the body through multiple routes $[2-4,10]$. These observations raise concerns as to whether workers at wastewater treatment plants are at an increased risk of exposure to lead and cadmium. Therefore, we wanted to first measure the level of lead and cadmium in blood of workers and, second, to investigate the genotoxic effect of these elements on workers' DNA. In this work, an effort was, also, made to identify the mechanisms by which this, possible, genotoxic 


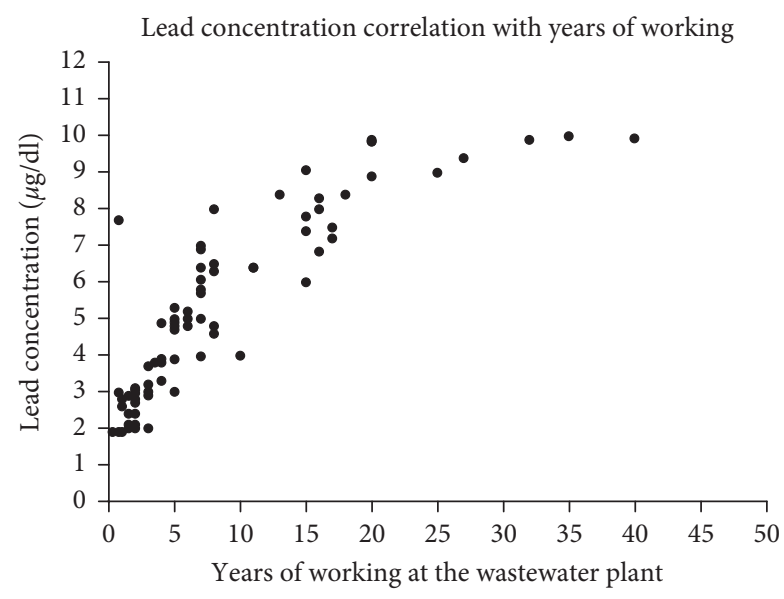

(a)

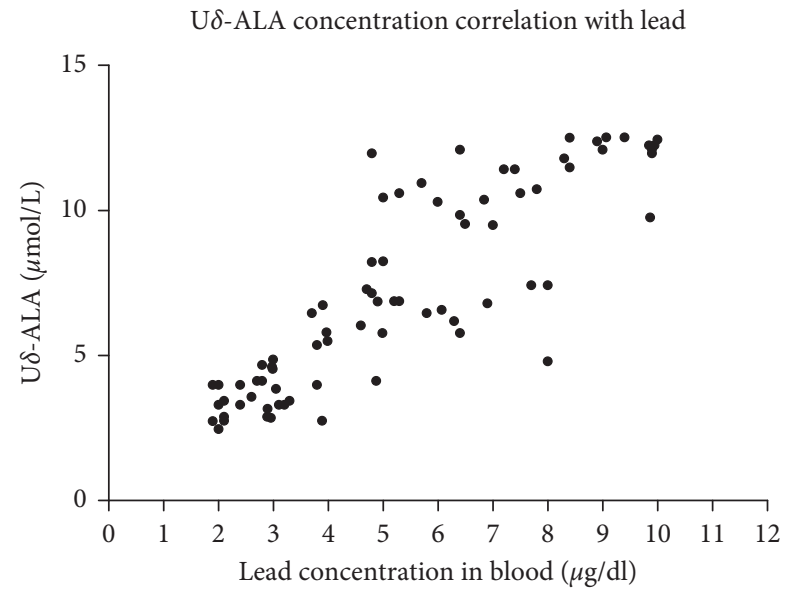

(c)

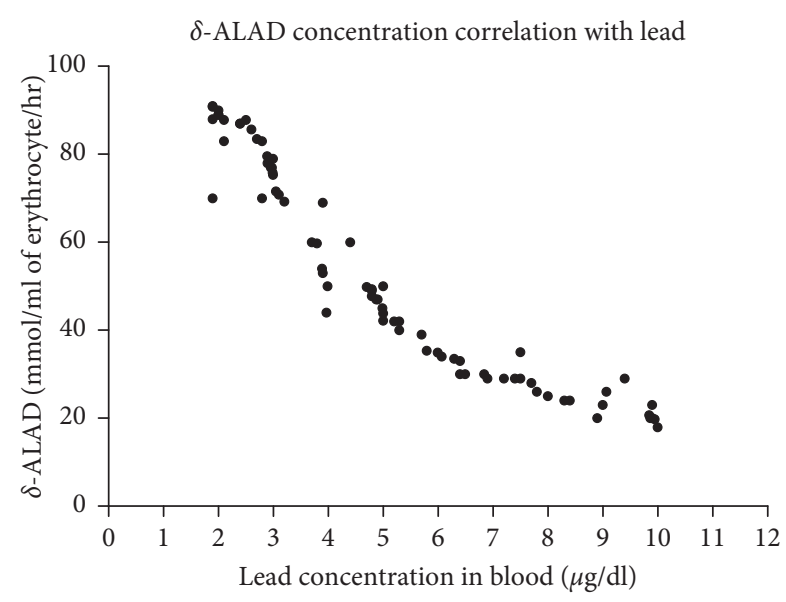

(b)

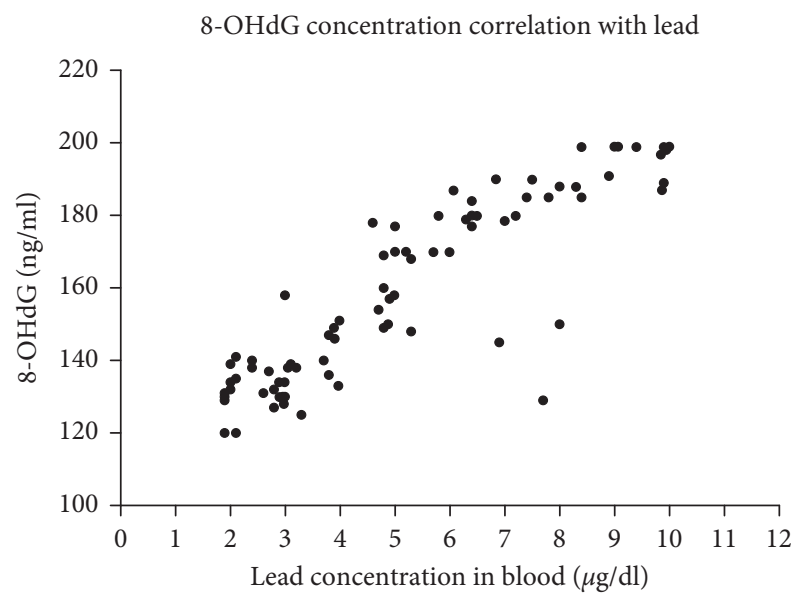

(d)

FIGURE 2: The correlation between years of working with the lead concentration and other variables' $(\delta$-ALAD, U $\delta$-ALA, and 8-OHdG) level with lead concentration. (a) It is clear that the level of lead rises with the increase in the duration of working at the wastewater treatment plant; a statistically significant positive correlation is seen. (b) Inverse relation between lead level and erythrocyte $\delta$-ALAD activity. (c, d) A pattern of positive correlation between $\mathrm{U} \delta$-ALA and 8-OHdG with lead concentration, respectively.

effect occurs by measuring $\delta$-ALAD and U $\delta$-ALA, and ultimately, we evaluated the level of the DNA damage utilising 8 -OHdG as the representative marker.

We found that the level of lead was higher in the worker group compared with the control group. The mean level of lead in the worker group $(5.2 \mu \mathrm{g} / \mathrm{dl})$ was within WHO permissible blood lead concentrations of $<10 \mu \mathrm{g} / \mathrm{dl}$, which progressively increased with the duration of working [33]. This progressive increase can be attributed to lead's nature as a fat-soluble metal with long half-life that is readily absorbed when gets access to the body through ingestion, skin, and inhalation and accumulates in various organs $[8,13,20]$. The last two routes are most reasonable entry routes in our study setting similar to what was described in Sewer Worker's Syndrome [34]. Workers in the wastewater treatment plant and farmers using sludge as a fertilizer had higher level of lead [34]. Furthermore, higher levels were seen in workers in occupations that expose the worker to heavy metals such as mining, melting, and battery industry [35-37]. It might even affect people living in the vicinity of these industries [38]. A paper from Iran has shown that the resident of Tehran, the air-polluted capital of Iran, had level of lead and cadmium that was higher than WHO allowed limits [39].

Our results support the well-recognised finding that lead can inhibit the enzyme ALA dehydratase activity and, expectedly, will increase ALA in blood and consequently its excretion in urine $[12,13,16,17]$. Although some of the workers have had the same period of work at the plant and had the same levels of lead, their levels of U $\delta$-ALA were different due to the presence of single-nucleotide polymorphisms in the $\delta$-ALAD gene [30]. Despite $\delta$-ALAD activity inhibition, none of our study subjects had anaemia which develops when blood lead level reaches above $50 \mu \mathrm{g} / \mathrm{dl}$ [10].

ALA is known to be carcinogenic through production of 8-hydroxy- $2^{\prime}$-deoxyguanosine (8-OHdG), 8-hydroxyguanine (8-oxo-7,8-dihydroguanine), and 8-oxo-7,8-dihydro- $2^{\prime}$ deoxyguanosine (8-oxodG) [15]. Mechanistically, ALA generates reactive oxygen species which cause DNA base modification [15]. Similar to our finding, other studies observed a 




FiguRE 3: The mean concentration of cadmium in the wastewater treatment plant workers is almost threefold higher than the level found in the control group.

positive relation between $8-\mathrm{OHdG}$ and 8 -oxodG with lead [40-42]. Additionally, lead can induce DNA damage, on its own, without ALA mediation [14].

Cadmium toxicity is a global public health problem due to occupational and nonoccupational sources of exposure [13]. In this work, mean cadmium level was higher in the worker group in comparison with the control one, and the level increases with work duration, yet, still within the WHO acceptable level $(<0.5 \mu \mathrm{g} / \mathrm{dL})$ [21]. Workers at smelters and zinc ore refinery had much higher level of cadmium that is greater than the WHO limit, and the level progressively increases with the work period $[43,44]$.

Cadmium did not show the altered biochemical cascade, seen with lead, i.e., reduction in blood $\delta$-ALAD and increase in $\mathrm{U} \delta$-ALA and 8 -OHdG. It was previously shown that cadmium stimulates enzyme ALAD and antagonises the inhibitory effect of lead $[45,46]$. To add insult to the injury, another study contradicts the above finding and claims that cadmium inhibits ALAD activity and increases blood and urine $\delta$-ALA [47]. Indeed, it is possible that our relatively small sample size might have led to bias in results. The concentration and activity of any substance, including $\delta$-ALAD and 8 -OHdG, are not the functions of one factor only; rate of production and removal and inhibiting and activating factors are also involved. These depend on the tested tissue type and cellular milieu and, yet to be identified, other factors.

The absence of correlation between ALAD and 8-OHdG with cadmium does not mean the latter is not carcinogenic in our study setting. The well-recognised carcinogenic effect of cadmium is not necessarily delivered through ALA only; other mechanisms are involved such as genomic instability, epigenetic changes, and its estrogenic activity [20].

We have to keep in mind that lead and cadmium in blood represent a very small percentage (2\%) of their total amount that is present in the body [13]. Thus, it is considered misleadingly low and does not reflect the actual amount present in the body; it accumulates first in the tissue such as the bone and kidney and then the level reaches the plateau in blood [13]. Additionally, the WHO states that neurological symptoms can occur at lead level of about $5 \mu \mathrm{g} / \mathrm{dl}$, especially in children [33]. More sophisticated laboratory methods, such as urine provocation test, are needed to estimate the actual amount of cadmium in the body [13].

Our study is limited by its small number of cases; moreover, we measured only the blood level of the heavy metals which does not reflect the total body burden. Other methods to measure DNA damage or gene expression studies have not been used which can give better idea about the extent of genotoxicity. 


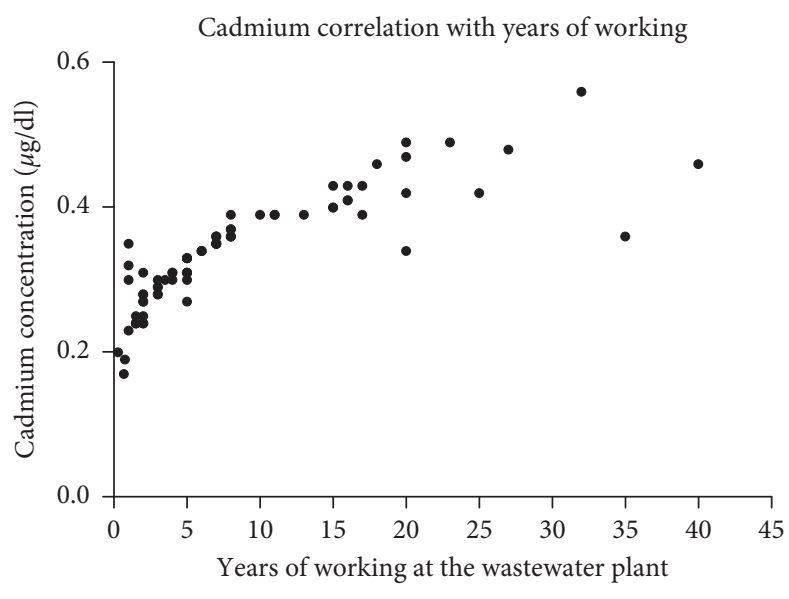

(a)

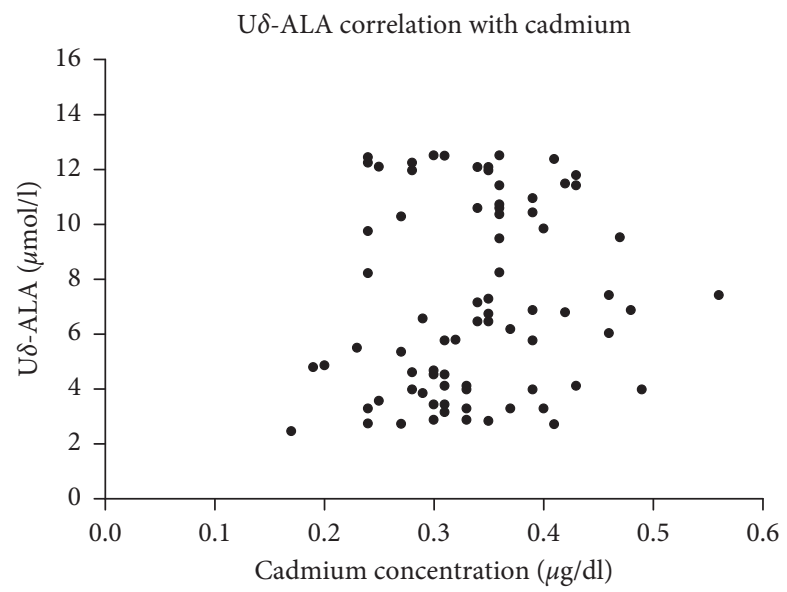

(c)

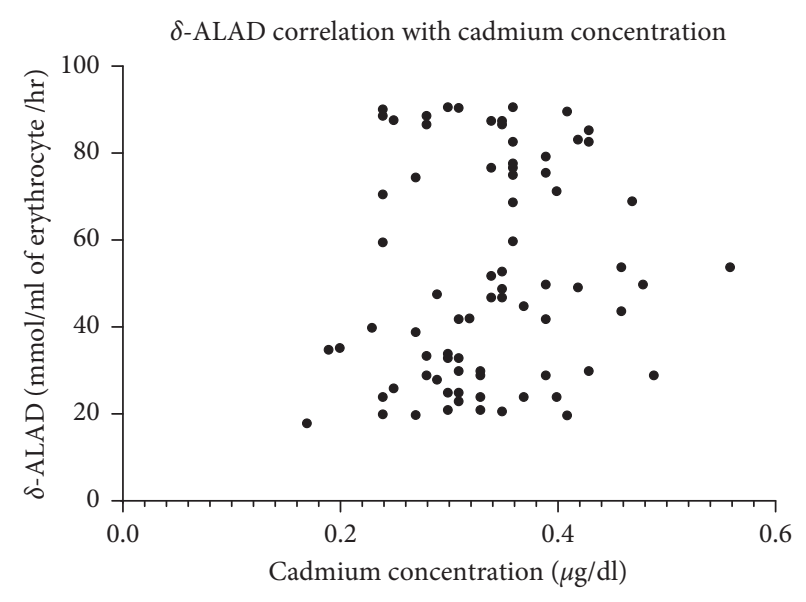

(b)

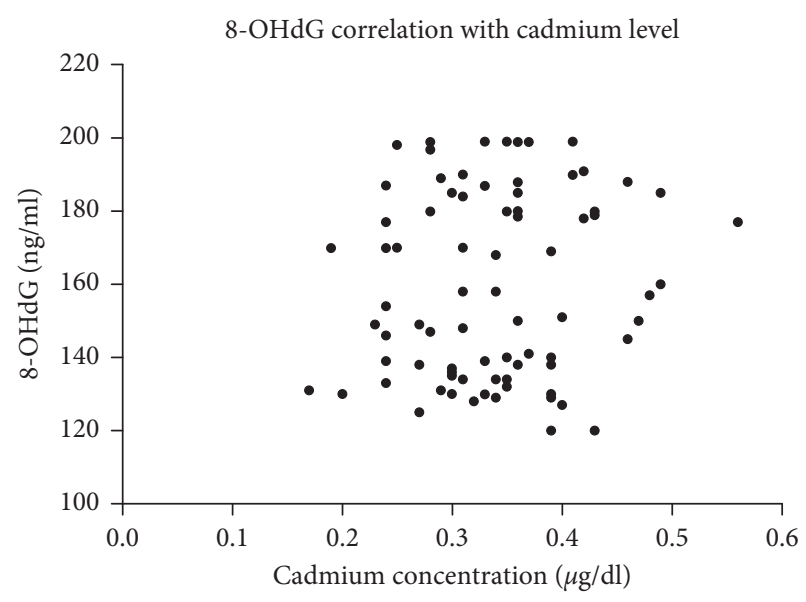

(d)

Figure 4: The correlation between cadmium and years of working and other variables' ( $\delta$-ALAD, U $\delta$-ALA, and 8-OHdG) level with cadmium concentration. (a) Concentration of cadmium increases progressively with the increase in the duration of working at the wastewater treatment plant; a statistically significant positive correlation is seen. (b) No correlation between ALAD level and cadmium. (c, d) Absence of any correlation between $\mathrm{U} \delta$-ALA and 8 -OHdG with cadmium, respectively.

\section{Conclusions}

To sum it up, both lead and cadmium are higher in the worker group relative to the control group. Lead has shown a greater association with DNA damage, using 8-OHdG as a marker, than cadmium. These observations should stimulate occupational health authorities and decision makers to search for strategies to reduce the exposure of the workers to the heavy metals and ultimately their subsequent health hazard. The presence of permissible limit should not be considered safe and assuring since the tissue level is not known and might be in the toxicity level. More complex laboratory methods should be used to estimate the actual heavy metal burden on the body. It is important to periodically monitor the level of these metals in blood and body and screen for their associated diseases such as various cancer and kidney diseases. Occupational health authorities should define a maximum work period at wastewater plants when workers have to relocate their jobs to places with less heavy metal exposure. This is especially important for those who exceeded the WHO permissible limit.

\section{Data Availability}

The data that support the findings of this study are available from the corresponding author (Salih Ibrahem) upon request.

\section{Disclosure}

The authors conducted the whole project from design, performance, and writing up solely with no support from any side.

\section{Conflicts of Interest}

The authors declare that there are no conflicts of interest.

\section{Acknowledgments}

The authors would like to thank the staff of the Department of Biochemistry, College of Medicine, Al-Nahrain University, for all the help and support during the work. Their 
thanks and gratitude extend to the Municipality of Baghdad for facilitating the work. This project was fully funded by the authors with no financial support obtained from any other parties.

\section{References}

[1] M. Salgot, E. Huertas, S. Weber, W. Dott, and J. Hollender, "Wastewater reuse and risk: definition of key objectives," Desalination, vol. 187, no. 1-3, pp. 29-40, 2006.

[2] K. Shamuyarira and J. Gumbo, "Assessment of heavy metals in municipal sewage sludge: a case study of Limpopo Province, South Africa," International Journal of Environmental Research and Public Health, vol. 11, no. 3, pp. 2569-2579, 2014.

[3] N. Ahmad, "Assessment of heavy metals in vegetables, sewage and soil grown near Babu Sabu Toll Plaza of Lahore, Pakistan," Pakistan Journal of Analytical \& Environmental Chemistry, vol. 20, no. 1, pp. 82-87, 2019.

[4] G. E. Üstün, "Occurrence and removal of metals in urban wastewater treatment plants," Journal of Hazardous Materials, vol. 172, no. 2-3, pp. 833-838, 2009.

[5] S. Khan, Q. Cao, Y. M. Zheng, Y. Z. Huang, and Y. G. Zhu, "Health risks of heavy metals in contaminated soils and food crops irrigated with wastewater in Beijing, China," Environmental Pollution, vol. 152, no. 3, pp. 686-692, 2008.

[6] A. Mahmood and R. N. Malik, "Human health risk assessment of heavy metals via consumption of contaminated vegetables collected from different irrigation sources in Lahore, Pakistan," Arabian Journal of Chemistry, vol. 7, no. 1, pp. 91-99, 2014.

[7] P. B. Tchounwou, C. G. Yedjou, A. K. Patlolla, and D. J. Sutton, "Heavy metal toxicity and the environment," Experientia Supplementum, vol. 101, pp. 133-164, 2012.

[8] V. N. Chigor, T. Sibanda, and A. I. Okoh, "Studies on the bacteriological qualities of the Buffalo River and three source water dams along its course in the Eastern Cape Province of South Africa," Environmental Science and Pollution Research, vol. 20, no. 6, pp. 4125-4136, 2013.

[9] R. C. Patra, A. K. Rautray, and D. Swarup, "Oxidative stress in lead and cadmium toxicity and its amelioration," Veterinary Medicine International, vol. 2011, Article ID 457327, 9 pages, 2011.

[10] D. A. Gidlow, "Lead toxicity," Occupational Medicine, vol. 65, no. 5, pp. 348-356, 2015.

[11] IARC, "Inorganic and organic lead compounds," in IARC Monographs on the Evaluation of Carcinogenic Risks to Humans, Vol. 87, IARC, Lyon, France, 2006.

[12] Y.-W. Chiu, T.-Y. Liu, and H.-Y. Chuang, "The effects of lead exposure on the activities of $\delta$-aminolevulinic acid dehydratase with the modification of the relative genotypes," E3S Web of Conferences, vol. 1, p. 26005, 2013.

[13] F. Scinicariello, H. E. Murray, D. B. Moffett, H. G. Abadin, M. J. Sexton, and B. A. Fowler, "Lead and $\delta$-aminolevulinic acid dehydratase polymorphism: where does it lead? A metaanalysis," Environmental Health Perspectives, vol. 115, no. 1, pp. 35-41, 2007.

[14] K. Danadevi, R. Rozati, B. S. Banu, P. H. Rao, and P. Grover, "DNA damage in workers exposed to lead using comet assay," Toxicology, vol. 187, no. 2-3, pp. 183-193, 2003.

[15] A. Valavanidis, T. Vlachogianni, and C. Fiotakis, "8-hydroxy$2^{\prime}$-deoxyguanosine (8-OHdG): a critical biomarker of oxidative stress and carcinogenesis," Journal of Environmental Science and Health, Part C, vol. 27, no. 2, pp. 120-139, 2009.
[16] R. R. Ray, "Haemotoxic effect of lead: a review," Proceedings of the Zoological Society, vol. 69, no. 2, pp. 161-172, 2016.

[17] M. J. Warren, J. B. Cooper, S. P. Wood, and P. M. ShoolinginJordan, "Lead poisoning, haem synthesis and 5-aminolaevulinic acid dehydratase," Trends in Biochemical Sciences, vol. 23, no. 6, pp. 217-221, 1998.

[18] T. Douki, J. Onuki, M. H. G. Medeiros, E. J. H. Bechara, J. Cadet, and P. Di Mascio, "DNA alkylation by 4,5-dioxovaleric acid, the final oxidation product of 5-aminolevulinic acid," Chemical Research in Toxicology, vol. 11, no. 2, pp. 150-157, 1998.

[19] A. Hartwig, "Cadmium and cancer," in Cadmium: From Toxicity to Essentiality. Metal Ions in Life Sciences, Metal Ions in Life Sciences, S. H. Sigel and R. Sigel, Eds., Springer, Dordrecht, The Netherlands, 2013.

[20] M. R. Rahimzadeh, M. R. Rahimzadeh, S. Kazemi, and A.-a. Moghadamnia, "Cadmium toxicity and treatment: an update," Caspian Journal of Internal Medicine, vol. 8, no. 3, pp. 135-145, 2017.

[21] J. Huff, R. M. Lunn, M. P. Waalkes, L. Tomatis, and P. F. Infante, "Cadmium-induced cancers in animals and in humans," International Journal of Occupational and Environmental Health, vol. 13, no. 2, pp. 202-212, 2007.

[22] Y. Wang, J. Fang, S. S. Leonard, and K. M. Krishna Rao, "Cadmium inhibits the electron transfer chain and induces reactive oxygen species," Free Radical Biology and Medicine, vol. 36, no. 11, pp. 1434-1443, 2004.

[23] L. Xu, W. Zhang, X. Liu, C. Zhang, P. Wang, and X. Zhao, "Circulatory levels of toxic metals (aluminum, cadmium, mercury, lead) in patients with alzheimer's disease: a quantitative meta-analysis and systematic review," Journal of Alzheimer's Disease, vol. 62, no. 1, pp. 361-372, 2018.

[24] R. Chowdhury, A. Ramond, L. M. O’Keeffe et al., "Environmental toxic metal contaminants and risk of cardiovascular disease: systematic review and meta-analysis," BMJ, vol. 362, p. k3310, 2018.

[25] A.-S. Abedi, E. Nasseri, F. Esfarjani, F. MohammadiNasrabadi, M. Hashemi Moosavi, and H. Hoseini, "A systematic review and meta-analysis of lead and cadmium concentrations in cow milk in Iran and human health risk assessment," Environmental Science and Pollution Research, vol. 27, no. 10, pp. 10147-10159, 2020.

[26] Y. A. Cho, Y. Kim, H. D. Woo, and K. Monsu, "Dietary cadmium intake and the risk of cancer: a meta-analysis," PLoS One, vol. 8, no. 9, Article ID e75087, 2013.

[27] L. Jouybari, M. Saei Ghare Naz, A. Sanagoo et al., "Toxic elements as biomarkers for breast cancer: a meta-analysis study," Cancer Management and Research, vol. 10, pp. 69-79, 2018.

[28] A. Y. Al-Sakini, "Rustumiya sanitation project and its effects on polluting diyala river," $A D A B A L-B A S R A H$, vol. 76, pp. 243-268, 2016.

[29] CLSI, Measurement Procedures for the Determination of Lead Concentrations in Blood and Urine, CLSI, Wayne, PA, USA, 2nd edition, 2013.

[30] K. S. Subramanian and J. C. Meranger, "A rapid electrothermal atomic absorption spectrophotometric method for cadmium and lead in human whole blood," Clinical Chemistry, vol. 27, no. 11, pp. 1866-1871, 1981.

[31] H. B. Burch and A. L. Siegel, "Improved method for measurement of delta-aminolevulinic acid dehydratase activity of human erythrocytes," Clinical Chemistry, vol. 17, no. 10, pp. 1038-1041, 1971.

[32] O. Wada, K. Toyokawa, G. Urata, Y. Yano, and K. Nakao, “A simple method for the quantitative analysis of urinary delta- 
aminol evulinic acid to evaluate lead absorption," Occupational and Environmental Medicine, vol. 26, no. 3, pp. 240243, 1969.

[33] World Health Organization, Lead Poisoning and Health, World Health Organization, Geneva, Switzerland, 2018.

[34] M. I. Greenberg, Occupational, Industrial, and Environmental Toxicology, Elsevier, Amsterdam, Netherlands, 2003.

[35] J. P. Buchet, H. Roels, A. Bernard, and R. Lauwerys, "Assessment of renal function of workers exposed to inorganic lead, calcium or mercury vapor," Journal of Occupational Medicine: Official Publication of the Industrial Medical Association, vol. 22, no. 11, pp. 741-750, 1980.

[36] M. M. B. Paoliello, E. M. De Capitani, F. G. da Cunha et al., "Exposure of children to lead and cadmium from a mining area of Brazil," Environmental Research, vol. 88, no. 2, pp. 120-128, 2002.

[37] K. Pala, A. Turkkan, S. Gucer, E. Osman, and H. Aytekin, "Occupational lead exposure: blood lead levels of apprentices in Bursa, Turkey," Industrial Health, vol. 47, no. 1, pp. 97-102, 2009.

[38] M. Fátima Reis, C. Sampaio, A. Brantes et al., "Human exposure to heavy metals in the vicinity of Portuguese solid waste incinerators-Part 1: biomonitoring of $\mathrm{Pb}, \mathrm{Cd}$ and $\mathrm{Hg}$ in blood of the general population," International Journal of Hygiene and Environmental Health, vol. 210, no. 3-4, pp. 439-446, 2007.

[39] L. Farzin, M. Amiri, H. Shams, M. A. Ahmadi Faghih, and M. E. Moassesi, "Blood levels of lead, cadmium, and mercury in residents of Tehran," Biological Trace Element Research, vol. 123 , no. $1-3$, pp. $14-26,2008$.

[40] K. S. Engström, M. Vahter, G. Johansson et al., "Chronic exposure to cadmium and arsenic strongly influences concentrations of 8-oxo-7,8-dihydro-2'-deoxyguanosine in urine," Free Radical Biology and Medicine, vol. 48, no. 9, pp. 1211-1217, 2010.

[41] A. Szymańska-Chabowska, A. Beck, R. Poręba, R. Andrzejak, and J. Antonowicz-Juchniewicz, "Evaluation of DNA damage in people occupationally exposed to arsenic and some heavy metals," Polish Journal of Environmental Studies, vol. 18, no. 6, pp. 1131-1139, 2009.

[42] X. Xu, W. Liao, Y. Lin, Y. Dai, Z. Shi, and X. Huo, "Blood concentrations of lead, cadmium, mercury and their association with biomarkers of DNA oxidative damage in preschool children living in an e-waste recycling area," Environmental Geochemistry and Health, vol. 40, no. 4, pp. 1481-1494, 2018.

[43] H. C. An, J. H. Sung, J. Lee, C. S. Sim, S. H. Kim, and Y. Kim, "The association between cadmium and lead exposure and blood pressure among workers of a smelting industry: a crosssectional study," Annals of Occupational and Environmental Medicine, vol. 29, no. 1, p. 47, 2017.

[44] N. J. van Sittert, P. H. Ribbens, B. Huisman, and D. Lugtenburg, "A nine year follow up study of renal effects in workers exposed to cadmium in a zinc ore refinery," Occupational and Environmental Medicine, vol. 50, no. 7, pp. 603-612, 1993.

[45] J. R. Davis and M. J. Avram, "A comparison of the stimulatory effects of cadmium and zinc on normal and lead-inhibited human erythrocytic $\delta$-aminolevulinic acid dehydratase activity in vitro," Toxicology and Applied Pharmacology, vol. 44, no. 1, pp. 181-190, 1978.

[46] S. Gupta, S. Bhosale, and K. Pandya, "Effect of simultaneous low level exposure of $\mathrm{Pb}$ and $\mathrm{Cd}$ on delta-ALAD and acetylcholinesterase activity in rats," Indian Journal of Experimental Biology, vol. 32, no. 11, pp. 819-821, 1994.
[47] C. Luchese, G. Zeni, J. B. T. Rocha, C. W. Nogueira, and F. W. Santos, "Cadmium inhibits $\delta$-aminolevulinate dehydratase from rat lung in vitro: interaction with chelating and antioxidant agents," Chemico-Biological Interactions, vol. 165, no. 2, pp. 127-137, 2007. 